\title{
Analysis of Urban Structure and Healthy City: Ede Metropolitan City In Perspective
}

\author{
Anthony Ikpeme Ankeli ${ }^{1}$, Muhammad Bashar $\mathrm{Nuhu}^{2}$, Abass IyandaSule ${ }^{3}$, Adegbile Moses Adeleke ${ }^{4}$, Oluwole \\ Titilayo Alabi ${ }^{5}$ \\ ${ }^{I}$ Department of Estate Management and Valuation, Federal Polytechnic, Ede, Nigeria \\ ${ }^{2 \&}{ }^{3}$ Department of Estate Management and Valuation, Federal University of Technology, Minna, Nigeria \\ ${ }^{4}$ Department of Estate Management and Valuation, The Oke Ogun Polytechnic, Saki, Nigeria \\ ${ }^{5}$ Department of Estate Management and Valuation, Yaba College of Technology, Lagos, Nigeria \\ Corresponding author*
}

\begin{abstract}
Recent studies on urban structures in Nigerian cities have focused on a work trip and transportation, urban decay, population explosion and urban land use crisis in major urban centres like Lagos, Kano, Abuja, Port Harcourt and Ibadan which are the main commercial centres and industrial hubs of the nation. Studies of urban spatial structure concerning city health in medium-sized cities and towns like Minna in Niger state, Akure in Ondo state and Osogbo in Osun have received little or no attention not to talk of smaller cities like Otukpo, Ede, Otan-Aiyegbaju, Saki and others in that category. The scantiness of these studies has made it difficult to have access to adequate and appropriate information and database for any effective and meaningful planning for urban planning and the health of inhabitants of cities in this category. Hence this study examines the internal structure of Ede metropolitan city concerning its health. Ede, the traditional home of the warlord in Yoruba land, is one of the most important towns in the old Oyo Empire. As a theoretical work, secondary data sources were explored to analyse the spatial structure of the city growth, health and land use. The study recommends among others the identification and replacement of the rundown structure, the provision of basic amenities and concludes that the adherence to the abovesuggested ideas will go a long way in ensuring a fair and sustainable healthy city in Nigeria that will be in line with the demand of the Millennium Development Goal (MDG).
\end{abstract}

Keywords: Urban Structure, Urban Theories, Healthy city, City Growth, Land Use

\section{INTRODUCTION}

$\mathrm{T}$ he unabated city growth rate or expansion in terms of space and population has become an issue of grave concern to urban planners/geographers, urban economist, land/city managers, sociologists and other stakeholders. It is more pronounced in cities of the less developed nations as Nigeria which have been described as a harbinger and a nation at the frontend of swiftly urbanising countries escalator (Ankeli, et al., 2019; Adegbola and Oluwale 2018). The perception that cities are the centres of political, economic and social powers is in itself a serious challenge ascity life is gradually becoming a norm and a dream of an average young Nigerian.Apart from the distortion of the urban structures, the unparalleled city population explosion has in most cities in Nigeria created problems of city heath, rental vivacity, ownership contestation and conversion or infiltrations of urban land uses.[21] observed that (urban structure) transformations taking place in our municipalities are of revolutionary magnitudes.Hence, the need for reassessment of urban planning, development and management for a sustainable city growth becomes essential. Professionals in the built environment and other related fields of studies have tried relentlessly and are still in the processof identifying and explaining the fundamental drivers of spatial patterns of urban growth and variations as it relates to city health in most cities of our modern world.

The report of the World Health Organization (2009) argued that urban settings benefit human health, especially where their needs for employment, hygiene, and nutrition can be sustained. The report further asserted that it could directly or indirectly endanger health. Direct health risks ensue when the inhabitants are not sufficiently protected against disease caused by the pollution of the soil, air, water or other forms of city activities or land uses. The degradation of urban and hinterland resources as ecosystem disruptions, low-quality urban spaces, inadequate waste management and flawed transportation system brings about indirect health risks.

As problematic, though interesting as urban structure idea is, no two cities have entirely the same growth pattern as the uniqueness in the growth of cities is most often influenced by factors ranging from economic, social, political, cultural, technological advancement to regional peculiarities. It is in line with this that previous studies of urban area or cities opined that each city exhibit similar but unique expansion or growth, land use patterns and health-related issues, thus resulting in the putting together of models by scholars to either describe or explain city structures in several parts of the world.

There exist no single definition or description that can convey the actual meaning of the term - urban structure, whichmay be due to the ubiquity of the idea. [23]opined that settlement population growth rates, physical expansion as well as her growth in terms of space for human needs are the main forces influencing land use activities. However, as there is nothing in 
life that is static, these forces are also said to be highly dynamic and are continually changing as change itself is said to be the essence of life. Though, previous studies revealed that the structure, form and shape of towns and cities despite their changing tendencies have a direct relationship with the spatial distribution of the culture/religion of the inhabitant, land use pattern and the health of the city ([31] and [25]). Presently there exist scanty research works on the analysis of urban structures and health city of medium-sized or lowerclass cities in the country. Such neglect is unhealthy and could pose severedevelopmental, management and health challenges for cities through ineffective urban land use planning and city organisation as these constitute the most noticeable feature of an urban area within the city land space.

Similarly, previous studies on urban structures in Nigeria focused attention on prime urban centres like Lagos, PortHarcourt, Abuja, Kano and Ibadan, which are the main commercial and industrial nerve of the country. Studies of an urban spatial structure as it relates to healthy city in mediumsized cities and towns like Bida, Kafanchan andOtukpo in the Northcentral Nigeria, Ede, OtanAiyegbaju andIlesa in Southwestern Nigeria or Mbidi, Orlu and Arochukwu in South-Eastern Nigeria have received little or no attention. The scantiness of these studies has made it difficult for researchers to have access to reliable, adequate and appropriate information and data on healthy city implication resulting from the poorly organised urban structure. Hence meaningful and useful planning and utilisation in the area of urban land use for most Nigeria medium and small size cities are fast becoming a mirage in recent time. The study was therefore conducted to engender spatial planning sustainability; integrate inclusive planning policies; conservation strategies and coherent, effective and efficient land use change that will provoke healthy city principles.

\section{THE STUDY AREA}

Ede isa historical and traditional town in Yoruba land that is politically dynamic and socially viable as well as an important city in the old Oyo Empire and the traditional home of Timi, Agbale.The population of Ede is said to have been rapidly experiencing unprecedented growth rate with the built-up areas experiencing physical expansion, due to its proximate location to Osogbo, the Osun state capital. The total population of Ede, a city in the present-day Osun state, according to the 2006 National Population Census, is 159,866 people.

Geographically, Ede is located south of Osogbo on Lat $7^{\circ} 4^{\prime}$ and $7^{\circ} 4^{\prime}$ North of the Equator and Long $4^{\circ} 2^{\prime}$ and $4^{\circ} 2^{\prime}$ East of Greenwich Meridian. The town is on the bank of Osun river that flows north-southdirection from Igede in Ekiti state. It is located in tropical rain forest belt with an annual rainfall of above $2,000 \mathrm{~mm}$ (78.7in). The study theoretically evaluates the internal urban structure of Ede metropolis and its probable health implications.

\section{THEORETICAL FRAMEWORK}

\section{City Growth, Healthy City and Urbanization}

According to Abonta, (2016), the formation and structure of cities are unique but what is familiar about cities is the fact that settlements and communities with a specific population, physical and economic features merged to become an urban centre. Thus, city growth can be looked at from demographic, economic and physical or geographical expansion perspective or the combination of all.

From whatever perspective urban structure and growth is view, [20] asserted that the increasing urban needs resulting from the rising rate of urbanisation in Nigeria have apart from the distortion of city morphology, brought about the current hyper-tripod problems of housing inadequacies, urban decay and appalling city structural arrangement in term of aesthetic and functions. The study further revealed that the few available necessary infrastructural facilities are being overused/over stressed leading to the total breakdown of essential services as electricity, potable water supply, inefficient city transportation system, low urban housing and health facilities among others. Consequently, [5], [6], [28] and [11] observed that the presence of infrastructural facilities helps in the restructuring of an urban area as it makes the entire urban structure to differ aerially from one part of the city to the other parts in term of its length or form.

Most Nigeria urban sub-space is facing the tripod problems of urbanisation, population explosion and urban land use pattern.

The city land use pattern depicts the complex structure of cities and the interdependent relationships among their various systems, the massive daily movements of people, goods and services from and to identifiable places of interest within the urban landscape as well as the health and safety of the city. [34] revealed that in considering the urban structure of a city, the non-inclusion of space, location and other land use consideration as a fundamental ingredient for any important proposition of urban economics should be an unthinkable exercise as the essence of a city lies in its proximity of diverse activities and persons. However, as a significant public health challenge of the $21^{\text {st }}$ century, the rapid increase in population, incoherent urban land use and city expansion with insufficient provision for necessary social and infrastructural facilities and economic inequalities in our urban centres have resulted in significant social vices and health problems. Hence, [10] in a way equated urbanisation to globalisation as it can be seen as a social structural cause of health that can contest the ambitions of equity due to propensity of accumulation of wealth and power among urban elites.

The Chadwick report on Health of Towns by the British government in 1842 marks the origin of a healthy city idea. Healthy city involves the process of creating and improving the physical, economic, and social environment, the expansion of the resources of the communities that allows support in the performance of all functions of life and full utilisation of 
potentials. The outcome alone is not the target of the healthy city but the process itself. More recently, the Western Pacific Region launched the alliance for healthy cities in 2004 aimed at promoting cooperation and support of all member cities. Today most districts that embrace the healthy city idea have their activities organised through a series of ways or structures.

The early realisation of the apparent failure of the conventional public health approaches which lay much emphasis on disease prevention and treatment; its inability to address new health challenges and the need for a healthy cities concept as a move towards a more holistic methodology aimed at achieving comprehensive health policies within cities through the synchronisation of ideas of urban dwellers living conditions with city health was a blessing to city dwellers the world over.

It is in this light that programmes on healthy city are targeted at employing inter-sectorial action, integration of health protection and promotion activities through community and settlement participations.

\section{URBAN STRUCTURE AND CITY HEALTH - THE NEXUS}

A healthy city is a city that is concern about her health and the measures put together to ensure its health, safety and aesthetics. The connection between spatial expansion, land use and tenure insecurity, urban poverty and health risk has been well documented in the literature. However, findings from previous studies have revealed that the internal structure of a city, urbanisation trend and the city land use have a significant impact on the health and socio wellbeing of the inhabitant ([12]; [34]; [6]; [4]; [26] and [3]).

[22] evaluates cities and population health and observed that a large number of the world's population would live in the city by the year 2007 thus exerting increasing influences on the health of both municipal and non-municipal residents. The study revealed a relatively scanty work in the understanding of how and why population health affects cities. It also echoed the size and complexity of the determinants and absence of a unified framework that binds the multiple factors that influence the health of urban populations. [12] submitted that urban rental vivacity, effective management of developing nations population explosion, land use infiltrations or conversion, land contestation and other criminal predispositions are the significant challenges facing cities in the emerging countries. [22] presented the conceptual framework for studying how urban living affected population health. However, the conceptualised framework built on earlier health studies is based on the assumption that the population of an urban area is defined by its size; diversity; density and complexity. Health in urban populations was said to be a function of living conditions which is shaped by national municipal determinants and global trends.
In 2009, Max Lock Consultancy Nigeria studied Port Harcourt city. It reported that in the past four decades, the spontaneous and uncontrolled physical growth driven by rapid urbanisation had given rise to the appearance of high-risk settlements, notably alongside swamps in the waterfront. At the same time, the ever-increasing inner-city rentals and urban housing inadequacies have resulted in the daily formation of sprawl, shanty towns and slum settlement at the urban fringes as city low-income dwellers that cannot afford the inner-city rent are forced to settle in these high-risk neighbourhoods, exposed to all forms of diseases and flooding. While [4] observed that since 2011, the city of Ibadan flooding had caused the devastation of over 2,100 homes, road network disrupted as bridges and culverts destroyed with violent means of inhabitants" livelihoods and increased health risk. The researchers attributed the emergence of the city risks to among other things the spatial city expansion concerning population growth, poorly managed urban land development and infrastructures, the rising number of slum settlements and the insufficient provision of public service. [34] put the total cost and effect to around $\$ 40$ million. [27] agreed with the above assertion as they opined in their study of cities, theories and reality that, the health and general standard of living of a city will decline if the current housing arrangements that reflect segregation of different social classes or social categories are not curtailed. As the long-term result of poor or uncomfortable urban livelihoods would result in local housing situations that will not be able to sustain human populations to any degree.

It is not the complete non-presence of infirmity or diseases in a city or an urban area that makes it healthy but the inclusion of total wellbeing of the inhabitants in term of their social, physical and mental state as well as the aesthetics of the city itself. A healthy city is a city that is "complete" in terms of healthcare delivery system, necessary infrastructure provision and betterment of the city. The challenges of city health go beyond the mere provision of healthcare; hence it requires the efforts of all stakeholder. Cities like Hong Kong with a robust policy on enhanced district administration and community partnership, the result of the healthy city introduced some decades ago seems to be encouraging as their local environment is experiencing improvements through the healthy city initiatives.

\section{EDE URBAN STRUCTURE}

Twoelements essentially determine the urban structure of an area. The elements or functions are the types ofland use in term of areas or specific locations where events are taking place and spatial accumulation that signifies the built-up areas or the level of concentration and intensity of the various land uses. Ede metropolitan city, for instance, has and is steadily witnessing sudden population explosion in recent time which [13] and [14] have partly attributed to the presence of some newly established institutions of higher learning and its proximity to Osogbo the state capital. The existing land uses in the metropolitan city of Ede are residential, commercial, 
circulation/ road, open space, industrial and public space land uses.The most prominent land use in Ede is open space, $\mathrm{road} /$ circulation and residential land use with $29,152.54$ $(93.2 \%) ; 1,600.24(5.1 \%)$ and $487.91(1.6 \%)$ spatial extent as shown in table 1 below.

Table 1. Classification of land-uses in Ede (in $\mathrm{km}^{2}$ )

\begin{tabular}{|c|c|c|}
\hline Land use Type & Spatial Extent $\left(\mathrm{km}^{2}\right)$ & $\%$ \\
\hline Residential & 487.91 & 1.560182 \\
\hline Public & 8.06 & 0.025774 \\
\hline Institutional & 20.61 & 0.065908 \\
\hline Industrial & 0.05 & 0.00016 \\
\hline Commercial & 2.86 & 0.009134 \\
\hline Agriculture & 0.18 & 0.00056 \\
\hline Road/Circulation & $1,600.24$ & 5.117081 \\
\hline Open Space & $29,152.54$ & 93.2212 \\
\hline
\end{tabular}

Source: Adopted from Structure plan for Ede and Environ, (2013)

More so, the quality of housing types combined with the poor planning of the inner core of the urban environment and its political fortunes have led to land-use differentiations in the town which have directly influenced the pattern and structure of the city resulting in slum formation and other health challenges. The elite has their abode in the area called "country home to Owode axis while the low income and "the ordinary" people dominate the Alusekele, Agbongbe, Sanya and the other traditional areas of the city. There exists a mismatch between the Extent of the land area occupied by the built fabric and the existing administrative and institutional boundaries of the local government areas. The structural plan for Ede and Environ (2013) revealed that a reasonable proportion of Ede inhabitants resides in an unhealthy, overcrowded and substandard housing. The lack of infrastructural facilities and decaying physical conditions of most parts of the inner-city core presents the characteristics of slums.

Table 2: Housing Types in Osun state: Ede North, South and Egbedore Local Government Areas

\begin{tabular}{|c|c|c|c|c|c|c|}
\hline House type & \multicolumn{2}{|c|}{ Osun state } & \multicolumn{2}{c|}{ Ede South } & \multicolumn{2}{c|}{ Ede North } \\
\hline & No & $\%$ & No & $\%$ & No & $\%$ \\
\hline $\begin{array}{c}\text { Detached } \\
\text { Houses }\end{array}$ & $\begin{array}{c}452,51 \\
6\end{array}$ & 62 & 10,960 & 69 & 12,537 & 68 \\
\hline Local huts & 26,768 & 4 & 694 & 4.34 & 312 & 2 \\
\hline Flats & 94,111 & 13 & 1,540 & 10.0 & 1,897 & 10 \\
\hline Semi Detached & 44,614 & 6.1 & 929 & 6.0 & 776 & 4 \\
\hline Rented rooms & 95,740 & 13.0 & 1,679 & 10.5 & 2,579 & 14.0 \\
\hline
\end{tabular}

\begin{tabular}{|c|c|c|c|c|c|c|}
\hline Informal houses & 2,024 & 0.28 & 16.0 & 0.10 & 34.0 & 0.19 \\
\hline Other & 18,543 & 2.53 & 161 & 1.01 & 237 & 1.29 \\
\hline TOTAL & $\begin{array}{c}734,31 \\
6\end{array}$ & $\begin{array}{c}100 . \\
00\end{array}$ & 15,979 & $\begin{array}{c}100 . \\
00\end{array}$ & 18,372 & $\begin{array}{c}100 . \\
00\end{array}$ \\
\hline
\end{tabular}

Source: Adopted from Structure plan for Ede and Environ, 2013

Ede metropolitan city cut across the two local government areas of Ede north and south local government areas. The two local government areas have developed and fused almost to become a single city centre. The study, therefore, shows the housing types in Osun with specific emphasis on the traditional Ede settlements of Ede north and south. Table 2 revealed the existence of class inequalities and the lack of socially mixed in Ede, which transcend to other adjoining local government areas as Egbedore and Osogbo. The presence of traditional hurt was highest in Ede south (4.34\%) compare to Ede north (2.0\%) The Structure Plan (2013) recommended a comprehensive upgrading of thebuilt-up areasthat exhibiting slum characteristics in the inner core of the city.

Similarly, the problem of spatial expansion of Ede metropolitan city concerning disease transmission is yet another serious matter. The city is expanding in a way that it can no longer be contained within the municipal limits of the local government areas; hence have overlapped to other adjoining local government areas without matching the necessary infrastructure provided. The existing urban settlements grow and attach themselves to other nearby local government areas, thereby facilitating the fast transmission of diseases from one urban area to the other.Again, the unplanned neighbourhood especially areas around the traditional city core which exhibit a high degree of housing decay and infrastructures run down, the development of shanty towns/settlements without public amenities is an eyesore and a breed zone for all sorts of urban health problems.

However, the internal structure of Ede metropolis is not different from what is obtainable in other urban centres in the southwestern region of Nigeria. The uniqueness of the Nigerian urban structure generally will only be appreciated if the concepts of urban structures as propounded by earlier scholars are studied. In light of this, some of the urban growth models were briefly analysed.

\section{MODELS OF URBAN GROWTH- THE ANALYSIS}

Several models have been put forward to underpin or describe urban structure by scholars. The principal conventional and contemporary urban models are:

\section{Burgess Concentric Zone Theory of 1924}

The focus of Burgess urban theory is on the outward expansion and the socio-economic groupings of cities in Chicago. The model assumes a land area that gives equal advantages in all directions, that is, flat land with all its morphological features removed and gave little significance to 
the role transport systems can play in a city.The theory also assumed that inner-city land attracts the highest values, and such values declined rapidly outwards to give zoning of urban functions and land use. It further asserted that, in building ranking, the oldest buildings are either found at the city core or close to the city centre with varieties of well-defined socioeconomic and ethnic areas existing in the city.Areas proximate to the city centre and places of work are occupied by the poor due to transportation and housing cost. The complete absence of heavy industrial concentrations is another factor.

The theorist, however, admitted that despite its simplicity, it was definite to a place and at a time (the 1920s). Some of the assumptions as postulated by Burgess did not exist.

\section{Hoyt's Sector Theory of 1939}

Hoyt in 1939 studied 142 cities in the United States of America using eight housing variables. His study intended to account for the distributions of and the changes in residential patterns. Hoyt, like Burgess, postulated some fundamental assumptions with the addition of some few new factors: That wealthy people chose the best site because of their ability to pay; wealthy residents live distant from the industry but close to the major road because they could afford private cars or public transport; similar land uses agglomerate, while noncompactable land uses repel each other. This process led to a 'sector' development; areas along primary communication attract the highest rent and that the city expansion takes the form of wedges. He also claimed that once an area had developed distinctive land use or function, it tended to retain that land use as the city extended outwards.

Hoyt failed to incorporate the tendency of rapid city growth with car-based urban fringe, the annexing of smaller cities or settlements by bigger cities due to urban expansion, inner-city area redevelopment as well as the relocation of office accommodation, shopping and industry at the urban periphery in his model.

\section{Ullman and Harris, 1945}

The urban structure model of Ullman and Harris is complex but produces a more realistic model than those of Burgess and Hoyt. Unfortunately, the model turned out to be more descriptive than predictive considering the fact of contents of the model. However, the basic assumptions of the model include: contemporary cities are more involved in structure than as proposed by Burgess and Hoyt; cities grow from several independent nuclei and do not necessarily grow from one CBD; every nucleus has its independent function as each nucleus acts as a growth point; the model considered the possibility of bigger cities annexing the smaller one as a result of urban growth as Barnet and Croydon now form part of Greater London; the possibility of dispersing too large city functions to other cities with lesser functions, thus forming a new nucleus is another factor that needs consideration.

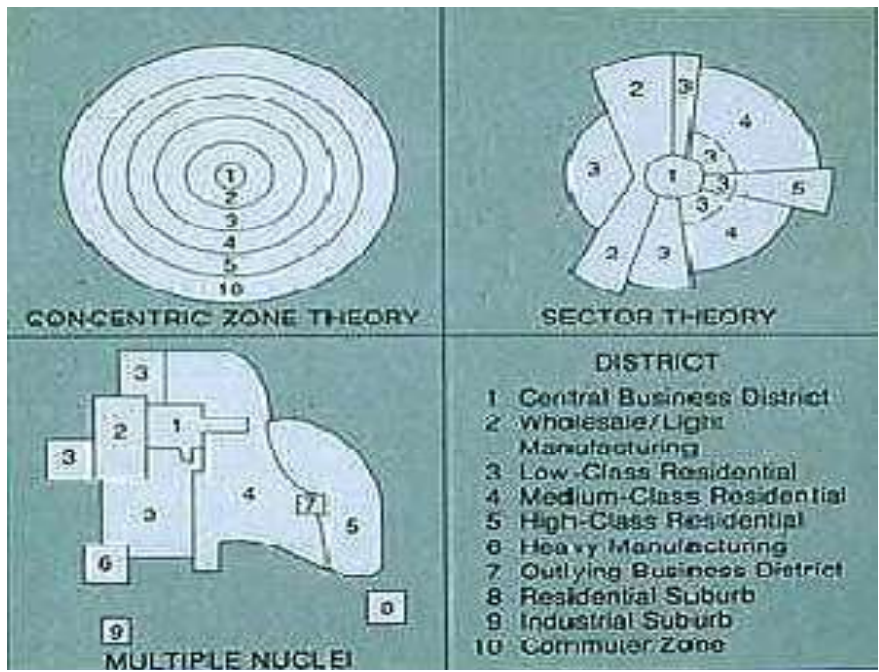

The Monocentric Model

The model suggested a robust high-density metropolitan area with an intense concentration of employment opportunities and other business activities, presence of adequate infrastructure and amenities that will require the regular transportation of goods and people from the urban fringe to the city centre. This kind of urban structure is a familiar structure in most cities in southwest Nigeria. The Oba's palace, which usually serves as the focal point, provided a ground for market and other commercial activities with streets leading from and to it. The monocentric model may not be the best model for the present-day Ede city as the traditional narrow roads with the Oba's market by the side, linking the palace to the other parts of the city is a significant source of traffic gridlock in the metropolis.

\section{The Polycentric Model}

The model did not propose the making of any city centre as the dominating city centre but advocate for uniform distribution of amenities, job and sub-centres across the builtup areas. The model occurs when settlements proximate to each other fuse (but with distinct identity and authority) as a result of urbanisation and development with randomised human and vehicular movement. This model may again not be the appropriate model for Ede metropolis due to its lack of resourcefulness.

\section{The Composite Model}

It suggested a dominant municipal centre with other several self-supporting districts and sub-centres. The self-supporting of the sub-centres is in the area of employment opportunities, organised vehicular and human Intra and inter movement of people across the urban area among others. The options help in the achievement of stable and sustainable urban growth through the spread of employment opportunities within the urban area. 


\section{The Stages of Urban Development Model}

[18] adopted and modified a proposed model of stages of urban development from Ogu, (2005), which provides the visual illustration summarising the evolution of Nigerian urban structures. The model explains the simple traditional core city, to colonial-era cities with separate low-density GRAs for the European settlers and isolated newcomers' quarters for internal migrants from other areas of the country, and finally to contemporary urban structures categorised by peripheral expansion and informal settlements surrounding the traditional core.

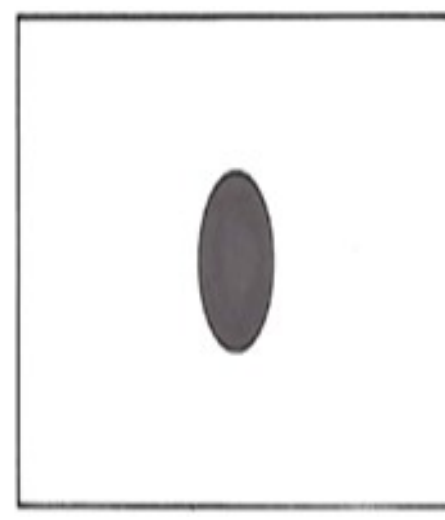

Source: Adopted from Adelakan (2009)
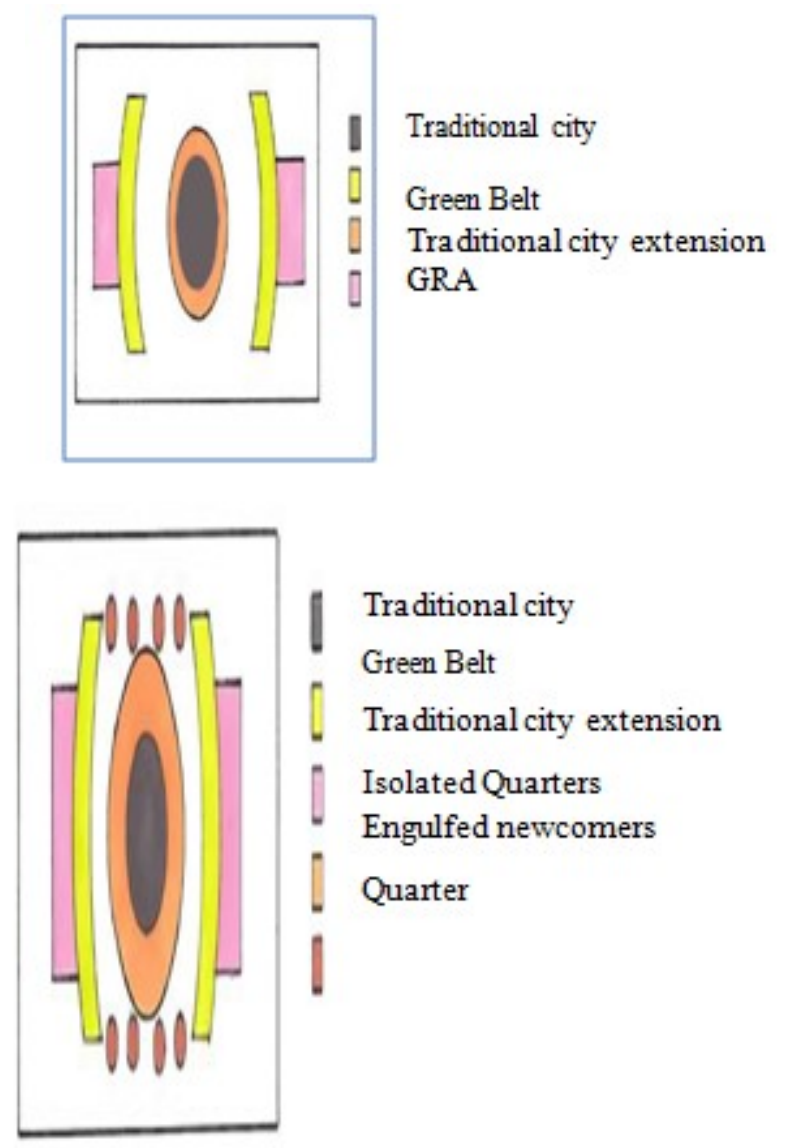

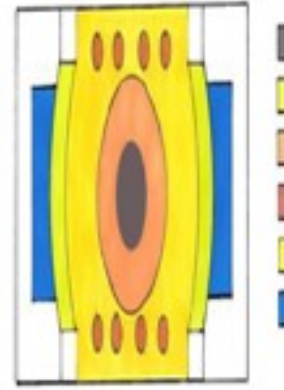

\author{
Traditional city \\ Green Belt \\ Decaying City \\ Engulfed Newcomer \\ Quarter \\ Penipheral Expansion \\ Redevelopment of \\ GRA
}

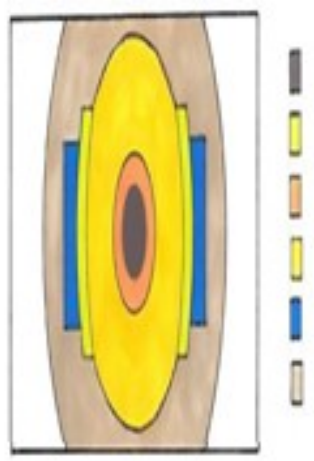

\author{
Traditional City \\ Shrinking Green Belt \\ Decaying Traditional \\ City \\ Intermediate Zone \\ Redevelopment of GRA \\ Peripheral Expansion
}

Source: Adopted from Bloch et al., 2015

\section{APPLICATION OF THE MODELS INEDE METROPOLIS}

Ede metropolis cut across two local government areas which are Ede South and Ede North Local Government Areas. Ede, shares boundaries with the state capital, Osogbo to the north on Osogbo-Iwo Road. To the east, the actual boundary is still in contestation. The need for the evaluation of the internal structure of Ede metropolis for it to maximise the proximity advantage to the state capital, maintain healthy city status among other benefits cannot be overemphasis.

Duhl\& Sanchez (1999) observed that the two primary rationales for urban planning are based first on the utopianism, idealism, symbolism and the expression of authority while the second rationale is based on the necessity for corrective measures due to natural disasters, human health hazards and the circulation of goods and people throughout an urban area. Similarly, it was furtherobserved that sociophysical settings of an area play a significant role in the health of the inhabitants, hence the need for the proper analysis of its structure. Ede metropolis has witnessed unprecedented growth in population, chaotic and uncoordinated physical development, overcrowding with diverse consequential effects for the teeming residents that flock to the city due to the presences of educational institutions and other similar establishments thereby making the township to gradually becoming unsustainable and progressively challenging to manage.

The opinion of most recent scholars in the academia concerning Nigerian city is that of complex units or sectors 
with several distinct districts with no specific functions and residential populations. Modern urban settlements in the country are polygonal and dynamic entities noticeable by the - frequently unordered - assemblage of the traditional core city and its residential, commercial and industrial zones with numerous new, typically suburban or peripheral areas, which arise in an array of configurations and social realities, and which contain a wide range of economic functions and social strata ([2]; [7]; [8]; [9]; [33] and [17]).

Ede is an excellent example of the above assertion. The city's urban morphology and various districts within the traditional core have transformed from the old single centre town to multiple centre city with a wide range of urban outlook. Thus, the city can be said to combine all the features of the traditional urban growth model with some noticeable element of polygonal and dynamic entities here and there. Even though the historic core of the city still exists, it has undergone through series of a significant transformation through the process of redevelopment which has taken it from the ancient small city to a relatively more decent and modern town in appearance. Though, pockets of informal settlements like the Alusekele and Sanya areas with the lowest quality buildings and high population densities that take care of the urban poor still exist. Another common feature of the city is the unplanned urban expansion at the city periphery, where institutions of higher learning are located and along major transportation routes. It has led to the emergence of commercial centres thereby creating yet another settlement districts as well as the peripheral informal settlements that give birth to slum and shanty towns which are a comfort zone for criminals and other social vices. The diversity of the urban form or structure enhanced the development of suburban residential or commercial nodes of the middle class.

These nodes have resulted in the emergence of a new urban centre within the existing urban area as they hold commanding functions. [18] opined that this process transforms the spatial organisation of socio-economic activity: with the appearance of new centralities influencing the entire metropolitan area and operating alongside traditional hubs. Ede Metropolitan city can be rightly described as a young urban settlement that is gradually transforming into or having a polycentric structure.

The structure plan for Ede and Environs (2014 - 2033) observed that the settlement pattern of Ede metropolis comprises of two different sectors which are the built-up older areas (usually characterised with haphazard and uncoordinated older buildings and developments, unplanned road system with congested traffic and unhealthy city life) and the sporadically developed areas with open land used for agriculture purposes. Ede city has four types of residential housing types which are: the Face-to-face (Brazilian type) with share toilets and other facilities; duplexes; blocks of flats; shanties. The study further asserted that residential accommodations accounted for about $87 \%$ of the developed area of Ede town; $8 \%$ of the land for commercial uses; $2 \%$ for religious use; $1.5 \%$ for institutional use; and $1.5 \%$ for industrial purposes.

Ede metropolitan area encompasses residential district as Owode, Abere, Aisu and Akoda and the older local villages as Alusekere, Sanya, Agbongbe and others that were absorbed and incorporated into the urban fabric as the city expanded. The urban structure thus incorporates multiple functional zones and terrains. The continuous expansion of the city has gone beyond the traditional line of Ede forming an extensive urban corridor with Osogbo the state capital, which is currently posing a severe problem of land encroachment between the two communities.

However, it has been observed that the practice of promoting health in a community by controlling exposure to the agents of disease is absent in the traditional core of Ede city. The condition of the inner city in terms of housing and health condition can best be described as appalling and unfit for human habitation ([2015]). Apart from the problem of housing inadequacies, most of the houses lack necessary infrastructure, thereby giving rise to serious health problems which could be attributed to the condition of the environment. The work of Hopton and Hunt (1996) which was carried out in an area with a history of housing challenges, high levels of poverty and poor health among adults confirmed the relationship between poor housing condition and city health, as the study revealed a positively significant relationship with children's health such as diarrhoea, wheezing and persistent cough living in unimproved housing. The rapid, chaotic expansion of Ede metropolitan city has made the city faced severe health and land use problems ranging from slum formation, infrastructure inadequacies, unemployment, housing shortages to loss of lives

It is thus evident that the urban structure of Ede metropolis in a way combined element of all the urban models discussed above- the Burgess, Hoyt, Ullman and Harris and the Mann's models as well as the monocentric, polycentric and the stages of urban development model by Bloch et al., (2015).

Although, the Bloch et al., (2015) model apply to and depict the internal structure of Ede metropolis than the other earlier theories/models.It considered the local environment and reaction of the people towards developmental activities. However, it clinched that the most appropriate city growth pattern or model for Ede metropolis is the composite model as it permits the development of all sectors - central and the urban peripheries.

\section{IMPLICATIONS AND CONCLUSION}

The study systematically evaluates the numerous developmental issues in Ede metropolis, especially issues concerning urban land use, development and growth among others were reviewed in order to establish how they affect urban structure and city health.It further reassessed the various city growth theories/models and concluded that the Bloch et al., (2015) model applies to Ede internal structure, but the 
composite model is the best model for the city as it allows for both urban and peripheral development. The study also found that awell-articulated healthy city programme could help in raising the awareness of the general public on health policies and issues; reduce health challenges and improve city dwellers standard of living through the provision of comfortable, natural, harmonious and enterprising environment. It revealed the implication of the unorganised internal structural arrangement of Ede metropolitan city, especially the inner core, which indeed have considerable effects on the health and aesthetics of the city.The study, therefore, recommended theidentification of rundown structures in the neighbourhood, provision of necessary infrastructures in the neighbourhood, renovation or replacement of rundown structures, economic empowerment and there should be firm and fair resolution and implementation of decisions and policies.

It is hoped that adherence to the above-suggested ideas will give birth toa new human settlement(Ede metropolitan city) that will be more efficient and sustainable and better able to meet the needs of her residents, ensure a fair and sustainable healthy city that is in line withMillennium Development Goal (MDG)objectives.

\section{REFERENCES}

[1] Abonta, R.E (2016). City Growth: Issues and Challenges of Urban Sustainability in Nigeria. Being a text of the $46^{\text {th }}$ Annual Conference Paper presented at the Conference of the Nigerian Institution of Estate Surveyors and Valuers held at Transcorp Hilton Hotel, Abuja on the $13^{\text {th }}$ April.

[2] Ade, M. A. \& Afolabi, Y. D. (2013). Monitoring Urban Sprawl in the Federal Capital Territory of Nigeria, using Remote Sensing and GIS Techniques.The Ethiopian Journal of Environmental Studies and Management.6 (1) 354 - 378

[3] Adelakan, I. O. (2009) Vulnerability of Poor Urban Coastal Communities to Climate Change in Lagos, Nigeria. $5^{\text {th }}$ Urban Research Symposium

[4] Adenjini, G and Ogundiji, B. (2009) Climate Adaptation in Nigerian Cities: Regularising Informal and Illegal Settlements in Ibadan $5^{\text {th }}$ Urban Research Symposium.

[5] Adetunji M.A (2010) Spatial Analysis of Urban Mobility Pattern in Ilesa, Osun State. Unpublished PhD Thesis Department of Geography, Obafemi Awolowo University, Ile- Ife

[6] Adetunji, M. A. \&Aloba, O (2013):Urban Spatial Structure and Work Trip Patterns in South-Western Nigeria: The example of IlesaJournal of Geography and Regional Planning. 6(4) 93-102.

[7] Aguda, A. S. \&Adegboyega, S.A. (2013). Evaluation of SpatioTemporal Dynamics of Urban Sprawl in Osogbo, Nigeria, using Satellite Imagery and GIS Techniques International Journal of Multidisciplinary and Current Research. Sept/Oct issue

[8] Ajala, O.A. \&Olayiwola A. M. (2013). An Assessment of the Growth of Ile-Ife, Osun State Nigeria, Using Multi-Temporal Imageries. Journal of Geography and Geology.5, (2)

[9] Alabi, M. O. (2009). Urban Sprawl, Pattern and Measurement in Lokoja, Nigeria. Theoretical and Empirical Researches in Urban Management 4 (13)

[10] Aliyu, A. A \& Amadu, L (2017). Urbanisation, Cities, and Health: The Challenges to Nigeria- A Review. Annals of African Medicine

[11] Aloba.O. (1989). The Structure of Work-Trips in Benin City, Nigeria Journal of the Faculty of Business and Social Sciences, University of Ilorin, Nigeria 1(1):63-81.

[12] Ankeli, I. A, Nuhu, M. B, Sule, I. A, Ankeli, U. C, Alade A. F (2019). Land Use Conversions and Rental Value Regime in an
Emerging City. The Awareness, Attention and Action. Proceedings of $74^{\text {th }}$ Researchfora International Conference, Hamburg, Germany, $4^{\text {th }}-5^{\text {th }}$ December.

[13] Ankeli, I.A. (2007). An Empirical Study on the Impact of Tertiary Institutions on Residential Properties Rental Values in a Developing Nation. A Case study of The Federal Polytechnic, Ede, Osun State. International Journal of Sciences, Engineering and Environmental Technology (IJOSEET), 2 (1). 97 - 107.

[14] Ankeli, I. A \&Akinjogbin, I.O (2008). Assessment of on the Job Performance of Polytechnic Graduates: A Situation Analysis of Federal Polytechnic Ede Graduands. International Journal of Sciences, Engineering and Environmental Technology (IJOSEET) 2 (1). 25 - 39.

[15] Ankeli, I. A, Daniel, I. D, Oyeleke, O. O, Guyimu, J, \&Oladimeji, E. J (2015). Housing Condition and Residential Property Rental Values in Ede, Nigeria. Conference of the International Journal of Arts \& Sciences, 08(01):53-61

[16] Ankeli, I.A, Ankeli, U.C, Sule, I.A, Nuhu M.B \&Kemiki, O.A (2018). Traffic Congestion and Urban Property Rental Values in An Emerging City: A Phenomenon always Overlooked. InternationalJournal of Arts \& Sciences, 11(01)115-128

[17] Atu, J. E; Offiong, R. A; Eni, D. I; Eja, E. I \&Esien, O. E. (2012) The Effects of Urban Sprawl on Peripheral Agricultural Lands in Calabar, Nigeria. International Review of Social Sciences \& Humanities 2(2) 119-128

[18] Bloch, R, Fox S, Monroy J. \&Ojo A. (2015) Urbanisation and Urban Expansion in Nigeria. Urbanisation Research Nigeria (URN) Research Report London: ICF International.

[19] Bijimi, C. K. (2013) The Relevance Of A Good Urban Design In Managing Urban Sprawl in NigeriaInternational Journal of Technology Enhancements and Emerging Engineering Research; 1(4)

[20] Daniel, I. D, Lawal, K.O, Adebowale, P. A, Ankeli, I. A and Gambo, M. J (2016). Infrastructural Facilities and the Rental Values of Residential Properties in Osun, Nigeria. International Journal of Business and Management Studies, 05(01):87-96

[21] Duhl, L.J \& Sanchez, A.K (1999) Healthy Cities and the City Planning Process: A Background Document on Links between Health and Urban Planning.Scherfigsvej 8 DK-2100 Copenhagen Denmark

[22] Galea, S., Freudenberg, N \&Vlahov, D (2005). Cities and Population Health. Social Science \& Medicine 60 (2005) 10171033

[23] GbadamosiK. T \& Ibrahim, S. A (2013): Land Use Conversion and Traffic Situation in Lagos, Nigeria: An ImpactAssessment of Victoria Island. Being the full length of a paper to be presented at 13th WCTR held in Windsor Barra HotelRio de Janeiro, Brazil, on July 15-18

[24] Hopton J \& Hunt S (1996) Housing conditions and mental health in a disadvantaged area of Scotland, Journal of Epidemiology Community Health 50

[25] Iravani, H \&Rao, V (2020). The effects of New Urbanism on public health, Journal of Urban Design, 25 (2) 218-235, DOI: 10.1080/13574809.2018.1554997

[26] Max Lock Consultancy Nigeria (2009) Port Harcourt Waterfront Urban Regeneration Scoping Study. MLC Press, University of Westminster, London, UK

[27] Odufuwa, B. O, Fransen, J., Bongwa, J and Gianoli, A (2009): Cities, theories and reality. Journal of Geography and Regional Planning 2(10) 243-248.

[28] Okoko, E (2008) Urban Transportation Planning and Modelling. Millennium Publishers Akure Nigeria

[29] Olujimi, Julius (s2009). Evolving a Planning Strategy for Managing Urban Sprawl in Nigeria. Journal of Human Ecology; 25 (3) 201-208

[30] Omole, F.K (2001): Basic Issues in Housing Development. Ondo, Nigeria, Femo Bless Publication

[31] Shearmur, R (2011). What Is an Urban Structure? The Challenge of Foreseeing 21st Century Spatial Patterns of the Urban Economy. A Working Paper, no 2011-06 prepared for 
SeminarioInternacionalCiudades,

Globalización. www.ucs.inrs.ca/sites/default/files/centre ucs/pdf/Inedit06-11.pdf

[32] Structure plan of Ede Structure and Environ (2014 - 2033). United Nations Human Settlements Programme (UN-HABITAT), 2014

[33] Tofowomo, Abimbola (2008). The Planning Implications of Urban Sprawl in Akure. 44th ISOCARP Congress 2008

[34] Washington DC, New York (2015): Department of Economic and Social Affairs
[35] World Bank (2014). Environmental and Social Management Framework. Ibadan Urban Flood Management Project (IUFMP), Final Report

[36] World Health Organization Report (2009). Urban Planning and Human Health in the European City. International Society of City and Regional Planners (ISOCARP) Version 09th June 